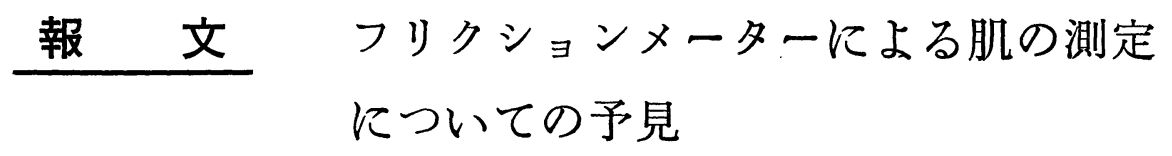

谷本文城 梨本道子

\title{
Application of Friction Meter for the Evaluation of Cosmetic Effects on Human Skin
}

\author{
Humiki Tanimoto, Michiko Nashimoto
}

\begin{abstract}
It is necessary in the evaluation of cosmetic products to get the user's tactile impression directly and objectively. The measurement of the friction on human skin surfaces, which may be one of methods to get the user's tactile impression directtly and obiectively, is important in the objective evaluation of cosmetic products.

Frictional measurements on the human skin surfaces were carried out on 12 subjects before and after the application of an emollient cream. Seasonal change, individual differences and the use of a toilet soap were found to affect the fricttion on the human skin surfaces. The frictional characteristic of the human skin surfaces after the application of an emollient cream was found to relate with the sensory attribute and also with the composition of oil phase in formulary of cream.

It was interesting to find that the frictional characteristic of the skin after an application of an emollient cream in the early winter corresponded to that of the bare skin in summer, and also that the difference of preference for the emollient creams related to the tendency of individual differrences of the friction values of the bare skin.
\end{abstract}

\section{1. 緒 言}

健康な皮膚は，角層中で脂質と水分がある一定量に保 たれて㧍り，表面は潤い，滑らかで美しくみえる。「皮 膚をすこやがに保つ」は，化粧品の定義の一つでもあ り，基礎化粧品使用者の使用意識といってもよいであろ う。そして化籸品使用者は, 視覚的にかつ触覚的に判断 して何らかの満足感を得るものと思われる。皮膚のフリ クションを測定することは, 使用者の触覚的な判断を直 接, 客観的に捕える一つの方法として意義あるものと考 える。

すでに J.K.Pral1 ${ }^{11}$ は, 皮膚の滑らかさの物理的要素 を測定するための機器を考案し,それらを用い, 皮膚の 感覚的な滑らかさに関する重回帰式を導いている。 本研究は, 機器特性としての皮膚のフリクション特性

(株)小林 ニーセー研究所, 東京都北区栄町 48-18 Research Laboratory, KOBAYASHI KOSE Co., Ltd., 48-18 Sakaecho, Kitaku, Tokyo
が，肌の状態とどう関連するのか，化粧品を塗布した場. 合に官能的判断とどら結びつくのかについて試みたるの であり，いくつかの知見が得られたのでここに報告す る。

\section{2. 実 験}

\section{$2 \cdot 1$ 機器測定}

$2 \cdot 1 \cdot 1$ 測定方法 フリクションメーター注1)の摩擦検出 部注2）を測定部位に一定荷重注3) で接触させ，一定回転 速度注4）で回転させたときのトルクを測定值とする。

(Fig. -1)

測定は，被験者 1 名につき 1 時間20分和き注5）に討 3 度行ない， 1 度につき左右の部位それぞれ4 回（荷重25 と50で 2 回ずつ）のくり返し測定を行なった。

注 1)（株）タケトモ慗作

注 2 ）直径 $10 \mathrm{~mm}$ ，エッジを丸めた円盤状，金属褩

注 3 ）荷重は装置の機構上直接に検出できながうたの で, 荷重の外部標準として, ハードネステネ゙タ 一を採用し，指針 0 から 25 まで，および 0 か 
ら 50 までに制御した（キャリブレーションの 結果, $220 \mathrm{gr}$. および $440 \mathrm{gr}$. に相当する。以下 荷重 25 , 荷重 50 と称す)。

注 4 ) $25 \mathrm{rpm}$.

注 5 ） 1 名につき約10分の測定時間を要するので, 実 験の都合上算出された值である。

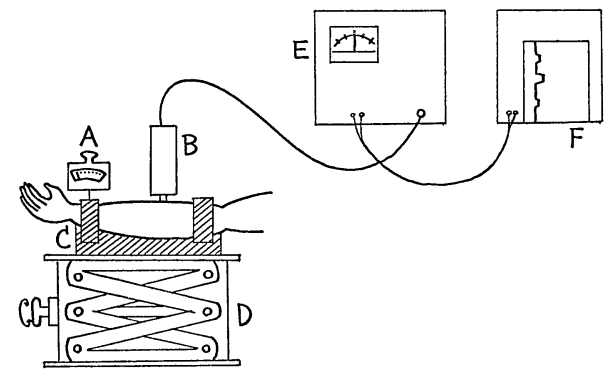

Fig. -1 Aapparatus for measuring the friction on human skin surfaces. (A ; Hardness tester, B ; Friction detector, C ; Box for settling the forearm, D ; Laboratory Jack, E ; Friction Meter, F ; Recorder)

$2 \cdot 1 \cdot 2$ 被験者 コーセー高等美容学校の生徒 12 名を対 象とした。Aグループ（男子 2 名, 18〜20才 : 女子 4 名, 17〜19才) 拈よびBグループ（男子 1 名, 20 才: 女子 5 名, 17〜19才, 32才)

$2 \cdot 1 \cdot 3$ サンプル 栄養クリーム 4 品 $(\mathrm{A}, \mathrm{B}, \mathrm{C}, \mathrm{D})$.

塗布方法 : 一定容量を一定面積に一定塗布動作で塗布 する。このときの塗布膜厚 ${ }^{8)}$ は概算で11〜 $12 \mu$ となる。 $2 \cdot 1.4$ 測定部位 左前腕屈側（素肌およびサンプル塗 布肌の測定）および右前腕屈側（素肌の測定）で測定を 行なった。

$2 \cdot 1.5$ 測定期間および測定室の 気象条件 被験者は 6 名ずつの A，B 2 グループに分かれ， S. 51. 6 月〜 S. 51. 12 月（ 8 月を除く）まで, ほぼ 1 週間ごとに, 各グ ループが 1 週交代で測定を行なった。

測定室の環境は, 温熱性発汗がないように, 温度につ いてのみ $20 \sim 24.5^{\circ} \mathrm{C}$ に制御した。相対湿度は 35〜86\% であった。

\section{$2 \cdot 2$ 官能検查}

2.2.1 検查方法 シェッフェの一対比較法 変形 3 (中 屋の変法）により，塗布中および塗布值後の 評価 5 項 目, 塗布 1 時間 20 分後の評価 6 項目および塗布 2 時間 40 分後の評価 9 項目について, 左右の手の甲を使用部位と し, 指先をたは手の腹との触感によって, 前記の栄養クリ 一ム 4 品に対する感覚的判断を, 5 段階尺度で行なった。
$2 \cdot 2 \cdot 2$ 被験者および検査期間 前記 12 名の被験者につ いては, S.51.9月〜S.51.12月にわたり, 機器測定と 同時に行ない, それに加えて, 専門家パネル女子 2 名は S.52.2月に行なった。

\section{3. 結果および考察}

\section{1 素肌のフリクション特性}

$3 \cdot 1 \cdot 1$ 季節的変化

女子について, 測定日ごとに素肌 (右前腕屈側) のフ リクション測定値の平均を求めた。(Fig. - 2, Fig. -3)

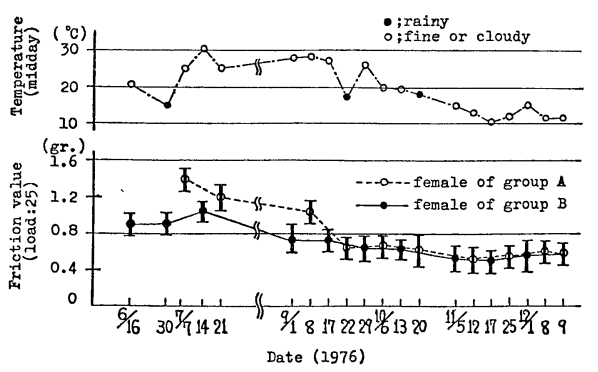

Fig. -2 The seasonal changes of the friction on human skin. (Load; 25), and the seasonal change of air temperature in Tokyo

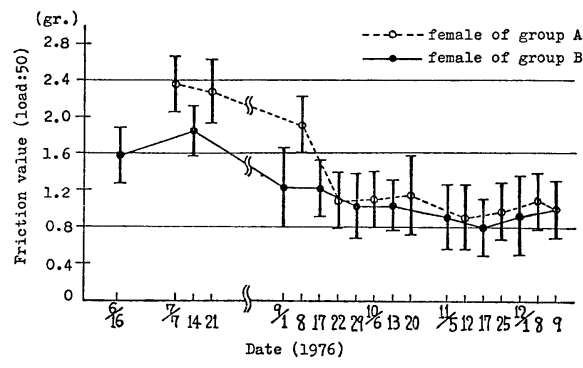

Fig. -3 The seasonal change of the friction on human skin. (Load ; 50)

グループの年齢構成が若干異なっているので，グルー プにより変化度合に多少差がみられるが，概して，6月 から 9 月上旬まではフリクション值は高く, 9 月下旬か ら12月までは低く，7月が最も高く，最も低い11月の約 2 倍に達しており, 有意な季節的变動が認められた。

一般に, 外界の気温の変化に伴って皮膚温も季節的変 動を示すと言われて和り2)，さらにそれに伴って皮脂排 出量にも季節的変化があると言われており ${ }^{3)}$ ，ここにみ られる素肌のフリクション值の季節的変化は, それと傾 向を共にするものであると予想される。 
合わせて，気象庁観測による東京都の気象（日平均） を示す。(Fig. -4)

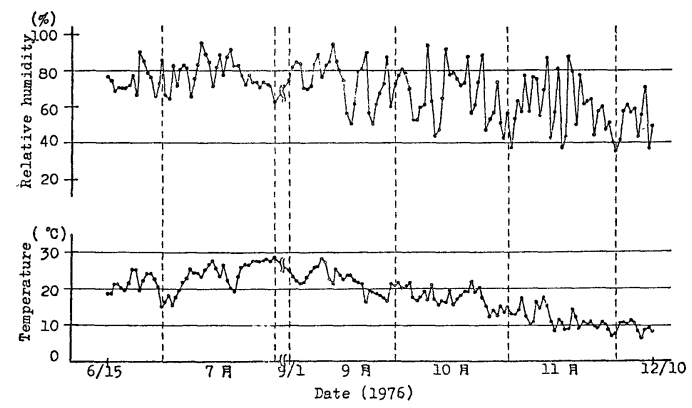

Fig. -4 The seasonal change of climate in Tokyo.

\section{$3 \cdot 1 \cdot 2$ 個人差（性差および年齢差）}

素肌（右前腕屈側）について被験者各人ごとに, フリ クション測定值の季節的変動の小さい 9 月下旬 $(9 / 22)$ から12月 (12/9) までのフリクション测定值の平均を 求めた。(Fig. -5)

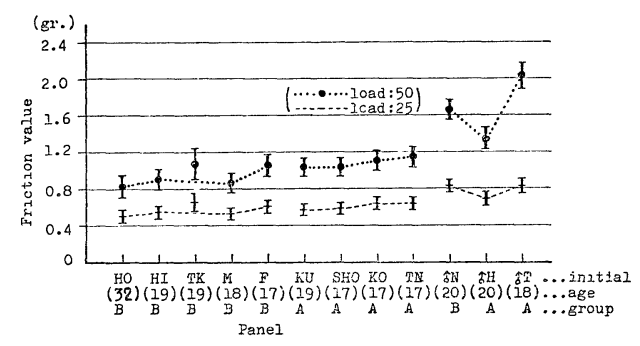

Fig. -5 The individual differences of the friction on human skin with diffe rences in age and between the sexes.

男子は女子よりもフリクション値は高く, 男子間には 影著な個人差がみられる。女子の間でも個人差が一部み られる。概して, 年龄の高い人は, 思春期 (16１8才頃) の女性に比べると, フリクション值は低い傾向にあり, 既婚者で最年長者が最も低い值となっている。 このように, 個人差とともに, 有意な性差, および年齢 差の傾向が認められた。これは, 一般に言われている3 皮脂排出量の年齢および性差の傾向に一致するものであ ると思われる。

$3 \cdot 1 \cdot 3$ 化粧石けん使用後の素肌のフリクション変化

Bグループ女子 5 名について, 化粧石けん使用後の一 定経過時間ごとに, 素肌 (左前腕屈側) のフリクション 測定値の平均を求めた。(Fig. -6)

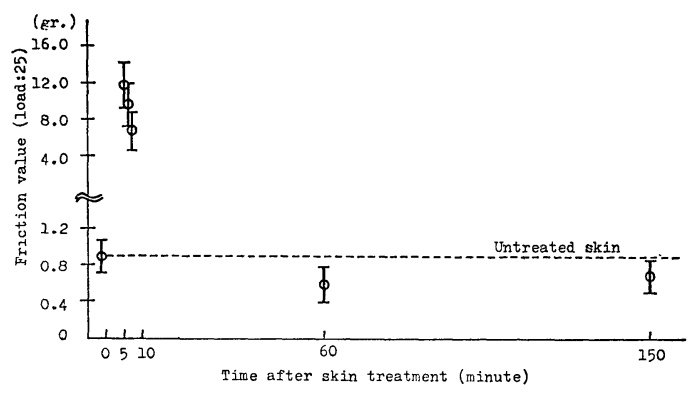

Fig. -6 The effect of a toilet soap on the friction of human skin (after washing with a toilet soap for 30 seconds, followed by rinsing for 30 seconds).

30 秒間化粧石けんで泡立てた後，30秒間水道水で洗い 落とし，タオルで軽く水気を拭き取ってから5分後に測 定を開始した。

5 分後には, フリクション値は非常に高い值を示し, その後秒きざタに值は急激に減少していき， 1 時間後に は，平常肌よりも有意に低小值を示し， 2 時間30分後に は, 值は平常肌の值に近つくく。

ここにみられる変化は，J. K. Prall ${ }^{1)}$ の実験結果とほ ぼ同じ傾向を示し，また，湿った肌のフリクションの值 は非常に高く，かさついた肌では正常肌に比べて低い值 を示すという A.F.EL-SHIMI) の報告と一致する。

そして，ここにみられる変化は，水分による湿った状 態の肌から, 水分蒸発の過程を経て, 石けんにより脱脂 された状態の，いわゆるかさついた状態の肌への変化, さらに, 時間経過に伴う皮脂の再分泌の過程への変化で あると解釈でさる。

以上, 季節的変化, 個人差の傾向, 化粧石けん使用後 の変化の $3 つ$ 観点から, 本実験に拈ける素肌のフリク ション特性は, 皮膚表面の皮脂量に関係があることが推 察される。

\section{$3 \cdot 2$ クリーム鉒布肌のフリクシ $ョ$ ン特性}

各サンプルについて, クリーム塗布肌（左前腕屈側） のクリーム塗布前の素肌に対するフリクシション測定值 の比をとって，各経過時間ごとにその平均を求めた。

\section{(Fig. -7)}

塗布 5 分後は, 各サンプル塗布肌は素肌の $2 \sim 4$ 倍で あり， C〜D>B>Aなる関係にある（有意水準 $5 \%$ ）。 塗布80分後は, 各サンプル塗布肌は素肌の1.8〜2.8倍 の間にあり，C>Aの関係がいえる（有意水準 $5 \%$ ）。 塗布 160 分後では, 各サンプル塗布肌は素肌の 1.8 倍 前後にかたまり，サンプル間にはもはや有意な差がある 


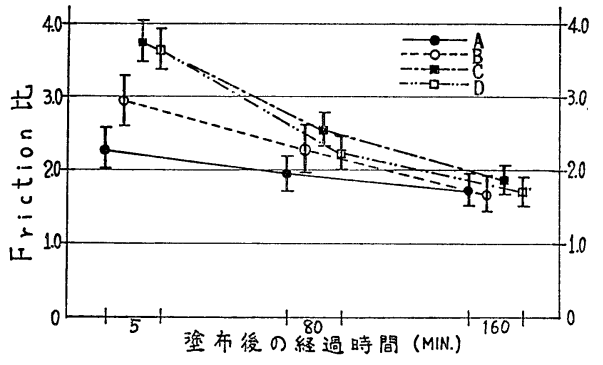

Fig. -7 The variations of the friction ratios between the samples

とはいえなくなる(有意水準 $5 \%$ )。

\section{3 サンプルの官能的評価}

各評価項目ごとに, $\left(\widehat{\alpha}_{i}-\widehat{\alpha}_{j}\right)[:$ サンプル $\mathrm{i}$ と $\mathrm{j}$ 対する平均咴好度の差]の95\%信頼区間から導かれたサ ンプルの大小関係の結果ををとめて Table-1 飞示す。

Table-1 Synopsis of the results of sensory evaluation $(n=10)$

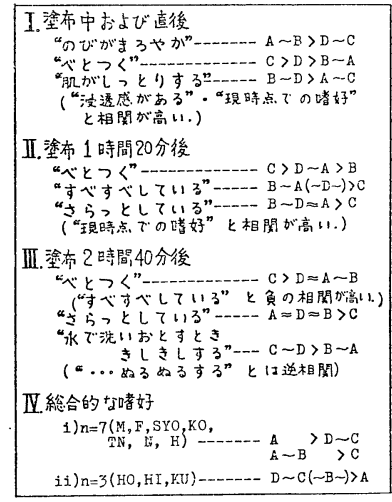

全体的に見た場合，塗布後時間が経過するにつれて， サンプル間にそれ程大きな差はなくなり，肌の状態の官 能的評価も困難になるものと思われる。しかし, 塗布 2 時間40分後でも，“水で洗い技とすとき，きしきしする

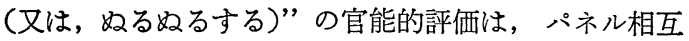
間の判断の一致もあり, サンプルの差の検出は容易であ るよらである。

消費者がよく使用する用語であり，栄養クリームに対 する㫮好々相関が高い項目の一つでもある, “肌がしっ とりする”の評価項目については，塗布 1 時間 20 分後 以降は, 専門家パネル相互間でもサンプルに対する評価 が異なっており，“しっとり感”の官能的な観念に対す る肌質の影響が一つとして考えられる。
塗布 2 時間 40 分後時点の “総合的な嗜好”では，パネ ル相互間ではっきりと赀好の差がみられた。7対 3 の割 合で,さっぱりタイプ嗜好とリッチタイプ莻好とにわか れた。

\section{4 クリーム塗布肌のフリクション特性と 官能的評価 との対応}

クリーム塗布肌のフリクション特性が何であるのかを わかりやすくするために，官能的評価との対応を試 み た。フリクション特性の物性值としては, サンプル塗布 肌の塗布前の素肌に対するフリクション測定值の比の值 （フリクション比）を用い, 官能特性の官能值としては, $\widehat{a}_{i}$ ( : サンプル $\mathrm{i}$ に対する平均蒈好度)を用いて, 物性 值と官能值との相関係数を求め, 相 関 係数の 絶 対值が 0.95 以上のもの（*印で示す） を相関が ある傾向にあ ると考えた。対応関係図を Fig. -8〜 Fig. -11 亿示す。

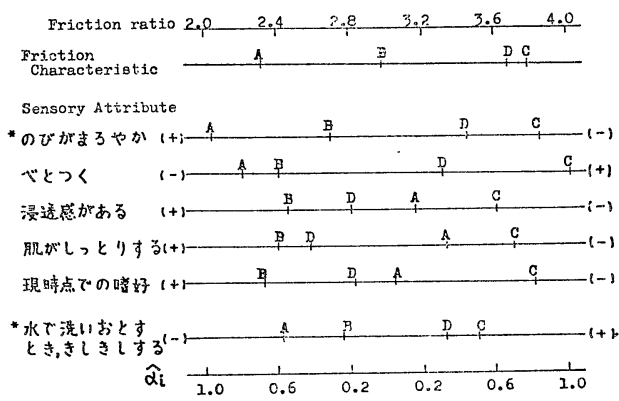

Fig. -8 The correlation between the frictional characteristic of the skin at the point 5 minutes after the application of a sample and the sensory attribute

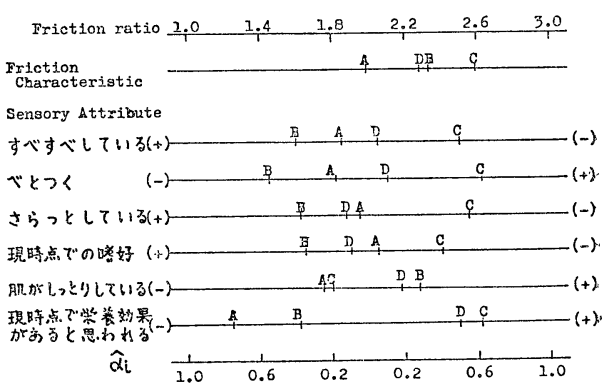

Fig. -9 The correlation between the frictional characteristic of the skin being applied of a sample and the sensory attribute at the point 80 minutes after the application of a sample 


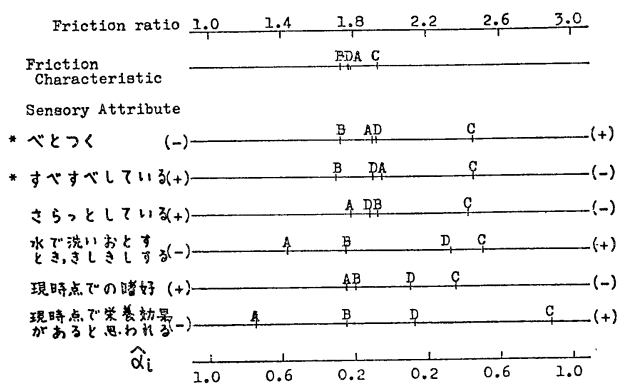

Fig. -10 The correlation between the frictional characteristic of the skin being applied of a sample and the sensory attribute at the point 160 minutes after the application of a sample

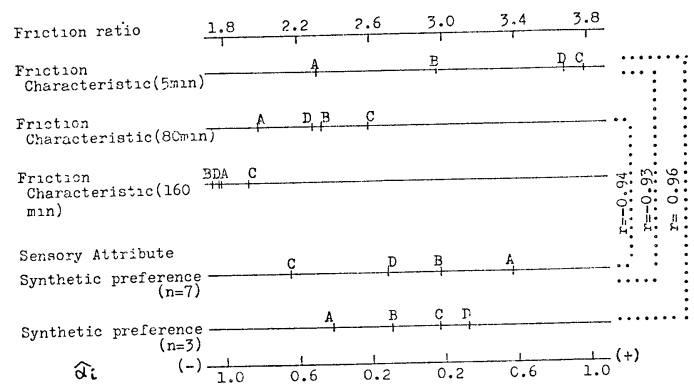

Fig. -11 The correlation between the frictional characteristic of the skin being applied of a sample and the "synthetic preference" of the sensory sttribute

塗布 5 分後では, フリクション物性特性は, 官能特性 の“のびがまろやか”と負の相関が高かった。さらに, 塗布 2 時間 40 分後時点の官能評価での“水で洗いおとす とき，きしきしする” と正の相関が高く，“水で洗いお とすとき，ぬるぬるする”と負の相関が高かった。

塗布 1 時間20分後では, 有意な対応関係は得られなか った。

塗布 2 時間 40 分後では, 物性, 官能ともにサンプル間 に大きな差はなくなり, 統計的に差がないところでの相 関ということになるが，フリクション物性特性は, 官能 特性の “ベとつく” と正の相関が高く, “すべすべして いる”と負の相関が高かった。

“総合的な嗜好” は, 塗布 5 分後, 塗布 1 時間 20 分後 のフリクション物性特性と比較的相関が高いことがわか る。

さらに, サンプ.ルの処方上の油分構成とフリクション
物性特性との関係について検討してみると, 塗布 $\mathbf{5}$ 分後 のフリクション物性特性は, 油系に占める固形油扣よび 半固形油の含量\%と正の相関が高く, 塗布 2 時間 40 分後 では, 油系含量と正の相関が高いことが得られた。

これより, 肌にクリームが塗布された直後のフリクシ ョン特性は, すべりに抢ける抵抗感であり, ある程度時 間が経過してからのクリーム塗布肌のフリクション特性 は, 粘着感関係するものであると解釈され得る。

\section{4. 総 括}

(1) 素肌関するフリクション特性は，発汗がない （皮膚表面が水分で湿っていない）状態では，皮膚表面 の皮脂量に対応するものであると考えられる。

(2) クリーム塗布肌に関するフリクション特性は, 塗 布時は“のびがまろやか”，一定時間経過後は“べとつ くせすべすべしている”の官能特性と対応関係がみら れ，さらにサンプルの油分構成に関係する。

(3) 興味あることとして, 初冬の素肌（前腕屈側飞括 いてではあるが）にクリームを塗布した状態が夏の素肌 にほぼ相当すること, 又, 皮脂排出量に個人差がみられ るように, 栄養クリームに対する嗒好の差も, 素肌のフ リクション測定值の個人差の傾向に従って現われたこと 等がある。

本研究では, 素肌関するフリクション特性で, 有意 な個人差拉よび季節的変化が認められたので, 官能的評 価汇括ける個人差执よび季節的㬐好差の一方面からの解 明に, フリクション機器が寄与する可能性が期待され る。そして, 今後の課題として, 被験者数, サンプル 数, 装置の荷重検出機構, 測定部位等の改良を検討した w。

\section{参 考 文 献}

1) J. K. Prall, J. Soc. Cosm. Chem., 24, 693 (1973)

2）安田利顕, 西山茂夫, 石川英一, 森 俊二, “皮 膚科検查” p. 142, (1973) 金原出版株式会社

3）桶口謙太郎, “皮膚科学特論” p. 74 75, (1969) 南山堂

4) A. F. El-Shimi, J. Soc. Cosm. Chem., 28, 37 (1977)

5）猪飼公郎, 椙山 勇, 新田初雄, 名市大医誌, 11，482-486 (1960)

6) 猪飼公郎, 椙江 勇, 新田初雄, 名市大医誌, 11, 863-866 (1960) 
7）椙江 勇, 名市大市医誌, 12, 1289-1296 (1962)

8) Mitsui, T., Morosawa, K., and Ōtake,C., J. Text. Stud., 2, 339-347 (1971)

9）安部 隆，日皮会誌，86 (12)，815-823 (1976)

10）篠原利明, 北浜坋夫, 科学警察研究所報告, 19
(4), (1966)

11）篠原利明, 北浜睦夫, 科学警察研究所報告, 20 (1), (1967)

12）篠原利明, 科学警察研究所報告, 22(2), (1969)

（昭和53年 4 月 5 日受理） 